\title{
The International Relations of the "New" Extraterritorial Approaches to Refugee Protection: Explaining the Policy Initiatives of the UK Government and UNHCR
}

\author{
Alexander Betts
}

\begin{abstract}
During 2003 there was an immense amount of debate about the possibility of states adopting extraterritorial approaches to asylum processing and refugee protection, and about such policies' compatibility with international refugee and human rights law. The debate has centred on two central policy initiatives: the so-called "UK Proposals" and UNHCR's "Convention Plus." It has so far focused primarily on the practical and legal consequences of these initiatives. What has been less clear is any explanation of the UK's (and other supportive states') motivation in aspiring to de-territorialize refugee protection and of UNHCR's strategy in the evolving consultations. After clarifying the conceptual and political relationship between the two sets of proposals, the article explores the motivation and international relations underlying them, from the perspectives of the UK Government and UNHCR.
\end{abstract}

\section{Résumé}

Dans le courant de l'année 2003, il y a eu beaucoup de débats sur la possibilité que certains états adoptent des approches pour le traitement extraterritorial des demandes d'asile, ainsi que sur la question de savoir si de telles politiques seraient compatibles avec le droit international et les droits humains. Le débat tournait autour de deux initiatives principales: ce qu'on appelle les «UK Proposals » ('La proposition britannique'), et Convention Plus de l'UNHCR. Il a porté jusqu'à présent sur les conséquences pratiques et légales de ces initiatives. Ce qui n'est toujours pas clair, c'est une explication quelconque des motivations de la Grande Bretagne (et des autres états solidaires) en voulant déterritorialiser la protection $d u$ droit d'asile, ainsi que la stratégie de l'UNHCR dans les consultations qui évoluent toujours. Après avoir éclairci les liens conceptuels et politiques entre les deux séries de propositions, l'article explore les motifs et les relations internationales qui les sous-tendent, du point de vue $d u$ gouvernement britannique et de l'UNHCR.

\section{Introduction}

$\mathrm{T}$ here has been a great deal of, often conceptually and terminologically confused, debate about the "new" extraterritorial approaches to forced migration. Throughout 2003 the details of what came to be called the "UK Proposals" for "transit processing centres" (TPCs) and "regional processing zones" (RPZs) were gradually leaked via the press. They became a concern for NGOs in the context of Home Office policy formation and a subject of intergovernmental negotiation at the EU level. ${ }^{2}$ Simultaneously, UNHCR began to reveal details of an initiative which it called "Convention Plus." This banner, initially proposed by Ruud Lubbers in September 2002,3 was widely used during the fifty-third Session of ExCom in October 2002, before it acquired any substance or detail. At this stage it was simply associated with ideas of creating a series of special agreements on the secondary movement of refugees and 
asylum seekers and "greater emphasis on ensuring lasting solutions in regions of origin." 4 It was only in the second half of 2003, in UNHCR's public statements surrounding the EU's Thessaloniki Summit and the publication of the Agenda for Protection, ${ }^{5}$ that the details of Convention Plus started to become more coherent.

Given the lack of clarity and the drip-fed nature of the details, it is not surprising that the two approaches were regarded as synonymous, especially by the UK media. The Economist, for example, defined Convention Plus as an "attempt to separate the concept of protecting asylum-seekers, to which the convention binds them [states], from that of admitting them to the country they want to go to," a definition widely regarded by UNHCR as more applicable to the UK Proposals. ${ }^{6}$ When this was written in February, UNHCR had given very little substance to its Convention Plus; yet the British government sought to align the two concepts. For example, in the New International Approaches To Asylum Processing and Protection document distributed in March, the Home Office attempted to associate its ideas with UNHCR, arguing that "this new approach draws on the UNHCR's plans for modernisation of the international protection system (Convention Plus)" and that "it would build on work already underway in UNHCR (Convention Plus)." Meanwhile, UNHCR, having constantly used its label in forums such as ExCom and the UN Commission on Human Rights, was forced into a post hoc formulation of its content. In doing so it distanced itself from aspects of the UK proposals, constantly making statements about what Convention Plus is not. It issued guidelines to NGOs, held a consultation on Convention Plus at the High Commissioner's Forum in June, and gave numerous press briefings clarifying UNHCR's position. ${ }^{8}$

Given the manner in which both sets of policy initiative emerged and evolved during the course of 2003, their details and relationship to one another require clarification and explanation. This article, therefore, seeks to explore two sets of questions. Firstly, what is the conceptual and political relationship of the UK Proposals and Convention Plus? Secondly, what are the underlying motives behind both the UK and UNHCR proposals and their response to one another?

\section{Extraterritorial "Protection": Definitions and Proposals}

Given the conceptual confusion, it is important to be clear from the outset about terminology and the relationship that the UK Proposals and UNHCR's Convention Plus have to one another. Extraterritorial protection ${ }^{9}$ may be defined as: the raft of refugee policies initiated by OECD countries aimed at de-territorializing the provision of protection to refugees in such a way that temporary protection and the processing of asylum claims take place outside of the given nation-state. It can take two distinct forms of policy approaches: firstly, third-country processing centres and, secondly, regional protection areas. The former was the central characteristic of Australia's "Pacific Solution," ${ }^{10}$ while both aspects (albeit in differing rhetorical form) have at various stages in the public debate been features of the UK Proposals and of UNHCR's Convention Plus.

While UNHCR has attempted to distance itself from the UK Proposals through numerous policy statements, the UK initially sought to identify its proposals with the emerging Convention Plus. Despite differences, the commonalities between the two sets of proposals have become increasingly apparent as UNHCR has clarified the substance of Convention Plus. Unsurprisingly, this has led concerned NGOs, such as Amnesty International, to identify UNHCR as complicit in promoting the substance of the UK Proposals. ${ }^{11} \mathrm{~A}$ conceptual definition of each form of extraterritorial policy will be given in turn, distinguishing at the same time between the UK's and UNHCR's position with respect to each.

\section{Third-Country Processing Centres}

Third-country processing centres are centres outside the recipient state to which spontaneous-arrival asylum seekers are sent and where they are effectively detained until their claims are assessed. Upon assessment of the claim, the asylum seekers are either awarded status and returned to the recipient state (or an alternative safe country) or else deported to their country of origin. ${ }^{12}$ This is the model that Australia has used on Nauru and Manus Island, as part of its Pacific Solution to deal with spontaneous-arrival asylum seekers. The UK's proposal explicitly drew its inspiration from that model and proposed a centre outside the EU's external borders to be managed by the International Organization for Migration (IOM). It was to be used to screen applicants from the controversial "white list" of states suspected of having "unfounded claims," currently already detained and fast-tracked, for example, in the UK's Oakington Reception Centre. ${ }^{13}$ After prior consultation with members of the European Council, ${ }^{14}$ the UK delegation proposed this initiative at the EU's Thessaloniki Summit in June 2003, where it recommended proceeding with and extending a pilot project bilaterally agreed with Croatia for such a centre to be built outside of Zagreb. This proposal was rejected by Germany and Sweden. ${ }^{15}$ The premise of this proposal was that it would be part of an EU burden-sharing initiative; ${ }^{16}$ as the Home Office document, New International Approaches, put it, "those granted refugee status would be resettled within the EU, on a burden-sharing 
basis." ${ }^{17}$ The EU rejection, as well as academic and NGO focus on the proposal's illegality and non-viability, ${ }^{18}$ seems to have caused the UK Government to drop this element of the policy. Caroline Flint MP said to the House of Lords Select Committee on EU Affairs (Sub-Committee F) on 29 October, "We are now focusing on the regional protection elements of our earlier ideas. We are no longer pursuing the concept of transit processing centres." ${ }^{19}$

Although UNHCR opposed the location of the EU's TPCs outside EU borders, it launched a counter-initiative to the UK's TPC initiative, which at various times has been explicitly identified with Convention Plus by UNHCR. Ruud Lubbers, for example, writes:

The UNHCR proposes separating out groups that are misusing the system, namely asylum-seekers from countries that produce hardly any refugees. These asylum-seekers would be sent to one or more reception centres within the EU, where their claims would be rapidly examined by joint EU teams. ${ }^{20}$

Given that even the UK proposals were directed at those from the controversial "white list" of states suspected of having "unfounded claims," the divergence between the two sets of processing-centre proposals is negligible. The key differences are on legal grounds rather than principle. The initial UK proposals set out the legal claim that: "The 1951 Refugee Convention obliges states to provide protection... There is no obligation under the 1951 Refugee Convention to process claims for asylum in the country of application."21 Meanwhile, UNHCR appears to confirm this position, Erika Feller, Director of International Protection, for example, stating that: "If an individual makes a claim in your state to your protection and you are a state party to the Convention it is incumbent on you to ensure that that person has access to protection, whether it is in your country or somewhere else" [emphasis added]. However, she makes the distinction that such a transfer of responsibility can only occur under limited conditions. These apply within the EU, she claims, because, firstly, there are common directives on human rights that ensure checks and balances and, secondly, the transfer is "from a unilateral responsibility to a system of common responsibility." ${ }^{22}$

\section{Regional Protection Areas}

Regional protection areas encompass a broader range of policies which are ostensibly intended to facilitate the provision of temporary protection to refugees within their region of origin, particularly in so-called "first countries of asylum." These proposals, although often vague, have covered two central elements: firstly, the idea of strengthened regional protection capacity and, secondly, a resettlement program based on "protected entry procedures." Both UK and UNHCR policy show considerable overlap, even consensus, in these two areas. For example, the UK's 2002 White Paper, Secure Borders, Safe Haven, refers to both elements. It welcomes the European Commission's study on the specific issues of both extending protection to refugees in their region of origin and establishing a European-wide resettlement program. ${ }^{23}$ With respect to regional protection it argues that: "we must discourage secondary movements by working internationally for a global system that delivers protection for those who need it." ${ }^{24}$ It explains the outline of a resettlement policy: "one possibility is for the UK to set a quota each year working closely with UNHCR to identify resettlement needs. We would set eligibility criteria to be used by UNHCR field officers, identifying suitable candidates." ${ }^{25}$ Very similar ideas are central to the vision of Convention Plus as laid out in Goal 3 of UNHCR's Agenda for Protection. ${ }^{26}$ This goal is summarized as: the desire "to work with States, particularly first-asylum States, to develop specific burden-sharing agreements that would be applied in response to mass influxes and to resolve protracted refugee situations." ${ }^{27}$ The central objectives of Goal 3 most relevant to states are those which advocate increased responsibility sharing with the South (objective 1), improved regional protection (objective 2), and the use of resettlement as a burden-sharing tool (objective 6). The similarities and differences between the UK and UNHCR approaches to each of the two areas of "protection in the region" and "protected entry procedures" can be explored in turn.

1. In terms of "protection in the region," the key distinction between the UK and UNHCR policies appears to be one of emphasis. The UK's New International Approaches document puts the accent very much on containment or, at least, "management" of "flows." For example, it flagged this element of the initiatives under the heading "measures to improve regional management of migration flows" and emphasized that "improving such protection would not simply benefit those who currently remain in the region: it should also reduce the incentive for the minority who do move on to Europe to do so." ${ }^{28}$ Meanwhile, UNHCR has been keen to place emphasis on protection. Lubbers explains, for example, "under the 'regional prong', the UNHCR is proposing a more coherent, wide-ranging effort by donor states to support refugees in the host country." 29 It has acknowledged in the Agenda for Protection, however, that these regional protection measures "should aim to reduce the need for asylum seekers and refugees to move on in an irregular manner by making protection available and generating solutions." 30

However, UNHCR has been keen to distance itself from the language if not the substance of the UK's ideas. It has 
attempted to distance its Convention Plus from many of the labels associated with the UK proposals. Janowski's statement, Setting the Record Straight, for example, rejects the notion of "safe havens" or "zones," explaining that UNHCR proposes inter alia "protection of refugees in the region of origin." ${ }^{31}$ Given the observation by Groupe d'Information et de Soutien des Immigrés (GISTI) that the phrase "regional protection zones" invokes connotations of historical protection failures such as the Srebrenica massa$\mathrm{cre}^{32}$ and Schuster's intimation that temporary protection zones might be established "along the lines of Sabra and Shatila," 33 the desire for clarity of distinction is understandable. UNHCR have, however, claimed that the distinction is more than semantic: Feller points out that the organization does not support the idea of closed camps but does support capacity building. ${ }^{34}$

2. On "protected entry procedures," there appears to be an emerging consensus between the UK and UNHCR in the form of a resettlement scheme. Noll, Fagerlund, and Liebaut define protected entry procedures as the diplomatic representation of a third safe country in the region of origin allowing non-nationals "to approach the potential host state outside its territory with a claim for asylum or other form of international protection" and "to be granted an entry permit in case of a positive response to that claim." 35 Its precedents are in the Danish visa office in Zagreb during the Balkan crisis and proposals that were put to the UN General Assembly by the Danish in 1986 and to the Intergovernmental Conference on Immigration, Refugee and Asylum Policy (IGC) by the Dutch in $1993 .{ }^{36}$ In October the UK and UNHCR together outlined a pilot resettlement project agreed with Ghana along the lines of these proposals. Under this scheme, 500 UNHCR-nominated refugees, victims of the Liberian civil war, were to be allowed to come to the UK. ${ }^{37}$ Iain Walsh, Deputy Director of the Immigration and Nationality Directorate, explained that:

The idea is that there will be some refugees in the region, in West Africa, that UNHCR feel that they will not be able to integrate into their areas and where return to their own country is not possible. Between ourselves and UNHCR we have identified a number of persons who are refugees and whom we think it is appropriate for them to spend their long-term lives in the UK. ${ }^{38}$

Beyond the heavy rhetoric and obfuscation that has characterized the debate on extraterritorial protection, it is this policy area that is most likely to emerge in a practicable form from the myriad of proposals. If developed beyond the pilot stage, such initiatives potentially change the basis on which asylum applications are made from a system of spontaneous arrival to one of a quota system based on protection and processing in the region. In this sense, if third-country processing centres are the Pacific Solution element of Australia's asylum policy for dealing with spontaneous arrivals, this aspect of the proposals draws upon the UNHCR quota system by which Australia takes 12,000 refugees per year, particularly via Indonesia. ${ }^{39}$ It is in many ways an attempt to return to the quota structure that existed prior to the growth of South-North spontaneous asylum in the 1980s and 1990s. Suhrke explains how this kind of structure facilitated multilateral burden-sharing arrangements for post-World War II resettlement and Vietnamese resettlement after $1975 .{ }^{40}$ The UK-UNHCR pilot implies that a similar structure may ultimately be adapted to couple protected entry procedures with an EU or a global burdensharing system.

\section{Exploring the Motives behind the Policies}

In examining ways of reconciling individual rights with state interests, the title of this special issue implicitly highlights a dichotomy common to many contemporary international relations debates: that between state security and human security. That these concepts are often in contradiction was the central premise of the critical security studies project that emerged as a post-Cold War challenge to the state-centric conceptions of security implicit to neo-realist approaches. By focusing on this tension, critical approaches to security have sought to show how, why, and for whom the "national interest" is constructed ${ }^{41}$ and how it often threatens human security both within and outside the state. ${ }^{42}$

In the case of extraterritorial protection policies, there has already been extensive work, by both academics and human rights groups, ${ }^{43}$ demonstrating how such policies may threaten the human security of refugees. Noll's work, for example, and its use by Amnesty International in their paper Unlawful and Unworkable, highlights the historical human rights consequences of the precedents for thirdcountry processing centres and of the use of concepts such as "safe havens" and containment. It also demonstrates the potential illegalities and impracticalities. What has been less clearly examined is the other side of the critical security studies dichotomy: the motivation behind state advocacy of such policies and the implications that this has for the actions of international organizations. In other words, what is it that has led the UK to identify these approaches as serving their "national interests" and why has UNHCR seen it necessary to adapt to the calls of states for such extraterritorial initiatives? As Eve Lester, Refugee Coordinator of Amnesty International, suggests:

We have to look at the underlying motives of creating these mechanisms where people are transferred to extraterritorial 
processing centres or to closed reception centres and consider whether they are designed to provide comparable protection or whether they are designed to provide something less than that. ${ }^{44}$

This is a difficult and inevitably exploratory task but it is worthwhile because an understanding of such underlying motives may be the first stage in challenging or re-aligning them if they are regarded as a threat to human rights. The motives of the UK and UNHCR will be explored in turn.

\section{The UK Perspective}

Understanding and theorizing about the behaviour of states is conventionally the central preoccupation of international relations (IR) theory. Neo-realists have tried to explain the "national interest" in terms of instrumental rational choice, neo-liberal institutionalists in terms of the interaction of norms and interests, constructivists in terms of the social construction of norms and expectations, Marxists in terms of materialism, critical theorists in terms of elites and power relations, and post-structuralists in terms of discourse. ${ }^{45}$ Except at the epistemological extremes, none of these need be mutually exclusive: all offer a partial explanation of international politics. ${ }^{46}$

Although both Steiner and Loescher are right to lament the lack of attention paid to the politics of refugee protection by international relations, a growing body of theory has attempted to conceptualize the motives that lie behind states' provision of refugee protection and its policy formulation. ${ }^{47}$ This has implicitly or explicitly drawn upon many of the assumptions of IR theory. For example, Shacknove has examined the ways in which U.S. provision of asylum serves "national interest" through its concern for political stability, economic stability, and foreign policy concerns. ${ }^{48}$ Loescher's early work on refugees and security analyzed the way in which recipient states often derived positive benefit from the provision of asylum during the East-West migratory context of the Cold War because of its symbolic use. ${ }^{49}$ Meanwhile, in the post-Cold War era of predominantly South-North forced migration, Loescher argues that, without the past strategic interests of the Cold War, "refugees were perceived increasingly as burdens, particularly if they made a claim for asylum in the West." ${ }^{50}$ However, as Steiner suggests, this approach hardly explains why states continue to provide asylum or why they choose the specific policies that they do. ${ }^{51}$

This has, however, begun to change. Steiner has shown, by looking at political debate on asylum in Germany, Switzerland, and the UK, how policy has been formed through a trade-off between "national interests" in terms of, for example, "internal harmony" and "effective governance" working in favour of restrictionism on the one hand and normative and ethical concerns maintaining the basis of the asylum system on the other. ${ }^{52}$ In the context of the EU burden-sharing debate, Thielemann has looked at the dynamics by which institutional and legal norms and the interests of political actors shaped the motives behind burden sharing. ${ }^{53}$ Meanwhile, the present author has looked at the benefits states derive from different types of refugee protection, both independently and as an international public good, by upholding a regime structure from which they derive security. ${ }^{54}$

These broadly theoretical approaches cannot by themselves explain the motives behind a specific policy shift such as New Labour's seemingly dramatic move towards advocating extraterritorial approaches to asylum. In looking at the formulation of public policy on asylum and migration in Germany and the UK, Boswell identifies factors that explain the formulation of policy over time: how refugees are constructed in public discourse, the international context, the perceptions and interests of the electorate, and the constraint of "embedded liberalism." ${ }^{55}$ Indeed this provides a useful starting point for assessing public policy evolution.

Assessment of New Labour's asylum and immigration policy is no easy task and is, necessarily, speculative in part. Flynn recently tried to explain the contradiction between the Government's increasingly liberal "economic migration" policy and its increasingly restrictionist asylum policy by arguing that New Labour's approach to asylum and migration is motivated by a utilitarian logic which attempts to act almost exclusively in favour of economic performance. ${ }^{56}$ In response others have suggested that this is a massive over-simplification and have pointed to factors such as the party's search for a "silver bullet" to "solve" the asylum "problem" through increasingly radical solutions. ${ }^{57}$ Whatever explanation one provides for Government policy, short-term political and institutional responses to managing media responses will inevitably play a part. However, Schuster rightly warns, "One should be wary of characterising this process as a completely ad hoc response to events." ${ }^{58}$ In reality, policy explanations will lie somewhere between monocausal metatheories and regarding policies as simply cyclical and ad hoc institutional reflexes.

It is with this in mind that this section attempts to explain the changes underlying the Government's perception of the asylum "problem" across four areas: economic cost, social cost, political cost, and international context. These categories overlap to a great extent with the central elements of policy input identified by Shacknove and Boswell, and build upon the theoretical model outlined by the present author in a UNHCR Working Paper. ${ }^{59}$ Within each of these exploratory categories, the interaction between public, media, and political perception will be explored, questioning 
whether the construction of these "costs" provides a "logic" for extraterritorial protection.

\section{Economic cost}

Noll reflects on the relationship between economic cost and extraterritorial protection and identifies something of a quandary. In examining the UK proposals for third-country processing centres in the light of empirical evidence from Australia's Pacific Solution, he argues that, far from reducing asylum costs, extraterritorial processing is vastly more expensive than the domestic processing of spontaneous arrivals, and that it is without any significant deterrent effect. ${ }^{60}$ This is indeed a paradox.

On the one hand, the UK proposals have arisen in the context of a national debate that has appeared to privilege, and even fetichize, the "cost" and "inefficiencies" of the current system. A series of recent headlines is testimony to this obsession: "Asylum Cost under Fire” (BBC), "Asylum Error to Cost UK Millions" (Guardian), "Letwin: Asylum Cuts Will Fund Policing” (Guardian), "Asylum Seeker Dispersal 'A Waste of Money"” (Guardian), "Asylum Cost Hits Eurotunnel" (Telegraph). ${ }^{61}$ Similarly, one of the explicit motivating factors behind the Government's extraterritorial approaches has been the allocation of resources. Caroline Flint MP has referred to the "imbalance" between UNHCR's US\$900 million annual budget to provide protection to 12 million refugees and 5 million IDPs compared with the US $\$ 10$ billion spent by just fifteen Western states on providing asylum for 500,000 asylum seekers. ${ }^{62}$

On the other hand, the "UK proposals" explicitly draw their inspiration from the Australian model, for which there is conclusive evidence that it raises the financial costs of processing asylum claims. For example, the majority of the AUD $\$ 1.2$ billion refugee budget increase in 2002-03 has been allocated to offshore processing, with $\$ 430$ million being allocated to processing in third countries in the Pacific (currently Nauru and Manus Island) and \$455 million on processing in Australian offshore locations (such as Christmas Island and the Cocos Islands) over the period 2002-03 to 2005-06. A further $\$ 219$ million was allocated for the construction of the facilities and $\$ 75$ million for transit costs. ${ }^{63}$ In terms of the comparative efficiency of domestic and offshore processing, the average cost to the taxpayer of offshore processing was $\$ 293$ per day on Christmas Island and \$236 on the Cocos Islands, against $\$ 87$ per day at Port Hedland, $\$ 65$ per day in Sydney, and \$102 per day at Woomera, for example. ${ }^{64}$ Similarly, the Refugee Council, basing its conclusion on the UK's recent expenditure on forcible removals, estimates that the transport costs alone of proceeding with its extraterritorial proposals would require an increase of $£ 1.5$ billion in asylum expenditure. ${ }^{65}$
Similarly, with respect to regional protection areas, the Immigration Law Practitioners' Association (IPLA) claims, "Even if there is a political imperative to reduce costs in relation to asylum, it is IPLA's view that the proposals for RPZs are unlikely to make any costs savings at all and indeed are likely to be cost intensive." The primary explanation they offer for this is, firstly, that constructing such an approach will require an additional layer of bureaucracy and, secondly, that it will create costs associated with identifying and returning asylum seekers to, say, an African refugee camp. ${ }^{66}$ The former explanation is clearly true as it will, particularly in the initial stages, require massive coordination between the host state, the UK, and UNHCR (and any other agencies involved). The latter reason depends very much on how the scheme is implemented. However, given that the deterrent effect of protected entry procedures relies very much on "successfully" dismantling alternative routes to spontaneous asylum ${ }^{67}$ and that deportation costs have already proved very high under the status quo, ${ }^{68}$ the prospects of cost-saving seem extremely limited.

\section{Social and political cost}

The perceived cost of hosting asylum seekers domestically is more than merely financial. Government policy will also be influenced by perceptions of social and political cost. The shift towards extraterritorial approaches is most appropriately seen as a continuation of the way in which the Government has sought to define and manage the "problem" of asylum since the massive growth in numbers of spontaneous-arrival asylum seekers from the South at the end of the 1980s and during the early 1990s. Since 1993, when the first piece of legislation exclusively aimed at asylum was introduced, the Government, rather than challenging media portrayals of refugees as a threat to the welfare state, national identity, and social cohesion, has sought policies that implicitly reify refugees as a "burden" by attempting to reallocate (or shift) that "burden.” Indeed, Robinson's work on the "burden-sharing" debate in the UK can be usefully extended to understand the logic behind extraterritoriality. ${ }^{69}$

Until the late 1990s the overwhelming majority of asylum seekers and refugees were spatially concentrated in London and the South East. ${ }^{70}$ This created what Robinson calls "sites of struggle" such as Dover and a number of London boroughs, where local media framing and hence public perceptions of rising economic costs created high levels of tension and violent clashes between local people and asylum seekers. With over 80 per cent of asylum seekers concentrated in the southeast, the Government began its policy of dispersal, formalized in the 1999 Asylum and Immigration Act, through which it established ten regional consortia to which asylum seekers were sent. ${ }^{71}$ As Boswell 
explains, dispersal aimed not only to redistribute financial costs, but also to reduce the social tensions arising from local concentration by physical transfer of the "burden."72

The problem according to Boswell, however, was that far from reducing social tension, dispersal exacerbated interethnic tensions because of the way in which it was carried out: many of the selected "cluster areas" were poorly chosen and often had already-resident ethnic minority groups; the new influx triggered significant inter-ethnic tensions involving not only the asylum seekers but also the local ethnic minority residents. She gives the example of Hull where, following the dispersal of 1,000 asylum seekers in spring 2001 , there was a significant increase in racist attacks. ${ }^{73}$ Similarly, in Glasgow, tension on the Sighthill Estate ultimately led to the murder of a Kosovar asylum seeker. ${ }^{74}$ These incidents achieved massive media attention which discredited the dispersal policy. That the "cluster areas" were ill-chosen is illustrated by the correlation between the areas chosen and the subsequent successes of the British National Party (BNP) in local elections: of the eighteen council seats won by the party by September 2003, half had been areas of the dispersal scheme: five in Burnley, two in Sandwell, one in Kirklees, and one in Stoke-on-Trent. ${ }^{75}$ In areas of inter-ethnic tensions the BNP was able to play the anti-asylum card with slogans such as: "While the dumping of asylum-seekers on our communities is fundamentally the fault of the Government, BNP Councillors will do everything in their power to prevent asylum-seekers being dumped in our areas." 76

Rather than challenge directly the construction of this "problem" by the extreme right and the media, the Government's response has been to accept the problem on these terms. It is in this context that the narrowing of physical space available to asylum seekers has been foreclosed. Robinson explains, drawing on Sibley, how "societies purify space by identifying 'residues' - the wrong things in the wrong place - and by eliminating them, or else moving them elsewhere. The nation state is one of the key actors in such spatial exclusion because it values conformity and social control." He argues that through media portrayal of asylum seekers the physical space available for the domestic provision of refuge has been eroded. ${ }^{77}$

Further exemplification may be drawn from the public response to post-dispersal policies such as the attempts to establish large-scale reception centres along the lines of those commonly found in continental Europe. Attempts to transform an Ministry of Defence site in Bicester into a reception centre for 750 asylum seekers have been scuppered by the challenge of the Bicester Action Group, which has gained widespread national support and extended its campaign to oppose all rural asylum centres. ${ }^{78}$ Similarly, on the outskirts of Newport in south Wales, the rural community of Langstone has formed Langstone Action and has mobilized to prevent a reception facility being established in the village. The link between media influence and fear is evident in comments by local residents, such as:

I am not prejudiced, by any stretch of the imagination, but you have only got to read in the papers what's happening with asylumseekers and it does make you worry. It is fear of the unknown. A lot of mums are worried about strangers not from the area hanging around. People are concerned about house prices. ${ }^{79}$

Such reactions, unchallenged by the Government, clearly limit the physical space that it is politically acceptable and electorally desirable for MPs to allocate to asylum seekers. Instead they have meant that within the context of asylum policy, political capital is more easily gained by "playing the numbers game." Alarmist and exclusionary statements have become increasingly commonplace. For example, Chris Mullin MP, Chair of the House of Commons Home Affairs Select Committee, declared the figure of 110,700 asylum seekers entering the UK in 2002 was "unsustainable" and gave the following catalogue of "inevitable" consequences:

If allowed to continue unchecked, it could overwhelm the capacity of the receiving countries to cope, leading inevitably to social unrest. It could also, and there are signs this may already be happening, lead to a growing political backlash, which will in turn lead to the election of extremist parties and extremist solutions. $^{80}$

That "physical presence" has, within the discourse, been constructed as the "problem" is evident by the Government's "fetichization" of numerical targets for "asylum cuts": in October 2002, David Blunkett set "targets" for halving the number of asylum applicants from a baseline of 8,900 claims per month to 4,450 by September 2003. By August 2003, with a reduction to 5,000 per month, he was able to proclaim "the kind of progress we have made is already a matter for celebration." ${ }^{\prime 1}$ This was achieved through measures such as the closure of Sangatte, the imposition of visa restrictions on Zimbabwe, and extending the white list to a further seventeen states. ${ }^{82}$ The "numbers game" is a direct consequence of increased identification of the "asylum burden" not with economic cost but with physical presence. In February, Tony Blair argued, "In the end the only way of dealing with this is to stop the numbers coming in. Once people get in, unless you can discover what country they have come from and get that country to agree to take them back, then it is extremely difficult to get them back." ${ }^{83}$ 
Linked to this is the political desire for control. As Schuster argues, the driving force behind UK asylum policy is "the need for control, to assert the sovereign power of the state and to ensure its stability by legitimating that control." ${ }^{84}$ Government discourse has been filled with such references. For example, in the foreword to the 2002 White Paper, the Home Secretary refers to the need for "trust" and "integrity." ${ }^{55}$ The need for "end-to-end credibility" is explicitly given as an underlying motive behind the proposals for a resettlement program in the Executive Summary. ${ }^{86}$ Meanwhile, the New International Approaches document gives falling public support for the status quo as one of its justifications for the "new" approaches. ${ }^{87}$

It seems evident that the Government believes reassertion of control would restore public credibility. Blunkett says, "I believe that men and women of this country will welcome those from across the world if they know what we are doing is trusted, and they can be confident in its administration." 88 The Australian precedent for extraterritorial protection offers evidence of how a qualitative distinction can be created between two sets of asylum seekers. There, the 12,000 quota refugees are seen as qualitatively different from the "queue jumpers" or spontaneous arrivals, who are regarded as pariahs. ${ }^{89}$ In the aftermath of September 11, high-profile media stories mean that spontaneous-arrival asylum seekers have been increasingly identified as a security threat. Reports about the discovery of ricin in a flat in London occupied by asylum seekers ${ }^{90}$ and the use of the system by former members of the Taliban, ${ }^{91}$ for example, create popular demand for "control" that can be met by a policy that externalizes the processing structure. In this context, the Government may believe that a public perception of increased control can be attained through the type of qualitative distinction drawn in Australia - between "threatening" spontaneous arrivals, on the one hand, and the externally vetted quota refugees on the other.

\section{The International Context}

Equally important to the UK Government is the imperative to work broadly within the constraints of international norms. Steiner's analysis of the role of legal norms and ethical concerns, grounded in liberalism and Judeo-Christian heritage, ${ }^{92}$ Boswell's analysis of the "constraints of 'embedded liberalism' "'93 and the work on the role of norms ${ }^{94}$ all imply that the international legal framework and, in particular, the 1951 Convention provide a regime structure that liberal democratic states are extremely reluctant to abandon. This is both because it forms part of their very identity as liberal democratic states, and at the same time upholds the collective action that underpins this regime structure and so provides collective (public good) security benefits.
The importance of these normative constraints in restricting the extent to which the UK has been prepared to pursue its extraterritorial initiatives unilaterally is revealing. The UK has attempted to work with UNHCR to negotiate its extraterritorial policies rather than abandon UNHCR involvement. It is notable that in the end the only emerging pilot project is the result of a joint UK-UNHCR initiative. Meanwhile, the UK has attempted to justify (rightly or wrongly) the legality of its proposals through reference to the 1951 Convention - implying that it still regards this as the basis of refugee protection.

Similarly, within the EU context, the Government's abandonment of the TPC proposals after their rejection by Sweden and Germany at Thessaloniki shows how the normative structures (and issue-linkages existing within the EU) restricted the potential for the kind of unilateralism available to the Australian and U.S. governments in establishing their third-country processing centres. This contrast highlights the fact that the norms and ethics of some EU states may positively constrain the initiatives by other member states to place restrictions on asylum provision.

\section{UNHCR: Between Catalyst and Barometer}

It is extremely difficult to infer precisely what kind of diplomatic dialogue has taken place between UNHCR and the UK Government over extraterritorial protection. What is clear, however, is that dialogue has taken place both as part of UNHCR's Global Consultations and more specifically in relation to the UK proposals and Convention Plus. UNHCR is necessarily in a difficult position: on the one hand it is an intergovernmental organization representing its member states and reliant upon their voluntary donations; on the other, it holds a mandate to uphold the 1951 Convention and provide protection to refugees. Where these dual imperatives come into conflict, as they increasingly do, UNHCR must find a strategic balance between the role as a barometer of state policy and that of catalyst for constructive influence on state policy, trying to lead and ensure refugee protection without alienating major donors.

Loescher explains how the emergence of South-North "jet-age" refugees and the ensuing unwillingness of states to admit refugees has brought UNHCR into conflict with states, in such a way that it has "ultimately lost the fight to maintain its position as the principal source of legitimacy and influence over refugee and asylum policy in Europe." He argues that this increasingly forced Sadako Ogata as UN High Commissioner for Refugees to frame policies in terms of state interests. ${ }^{95}$ Chimni further argues that, as an international organization, UNHCR relies upon the interests of a small coalition of hegemonic Northern states and that it "survives only if it continues to serve these interests." He 
suggests, for example, that during the 1990s UNHCR has "gone along with" initiatives such as "safe havens" and "safety zones" and has "sought to operationalize the containment of powerful donor countries" as a consequence of donor dependency. ${ }^{96}$ Meanwhile, Barutciski argues that, in the case of Bosnia, UNHCR was "subverted" to fulfill the containment aims of the EU states with its "safe havens" fulfilling the political objectives of its major donors. ${ }^{97}$ Dubernet, too, demonstrates how, in the case of Iraq, Somalia, and Bosnia, protection of IDPs administered by UNHCR (among others) was a tool of containment that failed to serve the human security interests of those displaced..$^{98}$ The present author has shown the empirical link between earmarked donations to UNHCR, based on state interests in containment, and the activities of UNHCR. ${ }^{99}$

Loescher, however, is marginally more optimistic about the role of UNHCR. He argues, "States remain the predominant actors. But this does not mean that international organizations like the UNHCR are completely without power or influence;" and "UNHCR has not solely been an instrument of state interests." For him, although state interests are the dominant factor, UNHCR has played a subtle role of "persuasion and socialisation." ${ }^{100}$ So, in the context of the extraterritorial protection debate, how has UNHCR balanced the roles of barometer and catalyst?

UNHCR is aware that Northern states have concerns about asylum. Lubbers acknowledges, "There are genuine concerns about the way the system is being managed, about the role of smugglers and about those who misuse the system by falsely portraying themselves as asylum seekers." ${ }^{101}$ Meanwhile, the Agenda for Protection acknowledges that an element of the motivation behind strengthening protection capacities should "aim to reduce the need for asylum-seekers and refugees to move on in an irregular movement by making protection available and generate solutions." 102 It is the use of words such as "irregular" to describe spontaneous arrivals, with its implication that regional protection and spontaneous asylum are mutually exclusive and its reinforcement of the logic of containment, that is likely to worry those who fear the Agenda is an attempt to pander to exclusion. This is exactly what UNHCR must avoid if it is to avert the disasters that came from containment in the 1990s.

The concern that UNHCR has been a passive barometer of UK interests throughout the debate has been put by Amnesty International. For example, Eve Lester, in discussing the proposal for third-country processing centres, said, "I know that the UNHCR position is quite compliant," impelling UNHCR to a better fulfillment of its obligations under Article 35 of the Convention to supervise state compliance with the Convention. ${ }^{103}$ Amnesty's Unlawful and
Unworkable was particularly concerned with the extent to which UNHCR's "counter-proposal" replicated many of the problems of the UK proposals, ${ }^{104}$ for example, oversimplifying the review procedure and undermining judicial supervision. The report also expressed alarm at the UK's overt statement in its New Vision paper that it hoped to use Convention Plus to turn UNHCR "into the organisation we would wish it to be." 105

Convention Plus appears to represent a compromise of UNHCR's mandate in order to meet the interests of restrictionism, though, an alternative way of reading it is that UNHCR is adapting to the realpolitik of state demands in order to influence them and fulfill its mandate subject to these constraints. The two key components of its mandate are to uphold the Convention and to ensure protection to its "population of concern" (predominantly refugees and IDPs in the South). On the first component, it would be easy to read Convention Plus as a dilution of the original Convention when faced with statements such as, "The 1951 Refugee Convention remains the cornerstone of the international refugee protection regime, yet it alone does not suffice. The Agenda for Protection is thus about building on the Convention. I call this the 'Convention Plus' approach." ${ }^{106}$ Yet, it could equally be interpreted as adaptation to ensure that states remain within the broad framework of the regime. Indeed, if any aspect of the debate has been encouraging, it has been the extent to which the UK, in spite of its proposals, has appeared willing to remain within the structure and has adapted its policies as a result of debate over the legality of its proposals under the Convention. On the second component of its mandate, UNHCR has managed, in part, to shift the debate away from simply processing towards protection in the region. If it can successfully direct states towards improved responsibility sharing with the South, then it may increase both voluntary donations and protection capacity.

Indeed UNHCR has not been passive in its relationship to the UK proposals, but has succeeded in contesting, and influencing, the UK. Erika Feller's words are indicative:

We do not like Regional Protection Areas. We have said it very clearly. What we do like, and I think this is something that one has to give a lot of credit to the UK for, is the innovation it has created towards improving protection in the region of origin. ${ }^{107}$

It shows how, once UNHCR improved its initially disastrous public relations campaign and clarified Convention Plus, it was able to engage constructively with the commonalities and differences between the two sets of proposals. It is unclear how much influence UNHCR has had on the UK; its abandonment of the transit processing centres, for ex- 
ample, may owe more to EU rejection in Thessaloniki than UNHCR diplomacy. However, whatever arguments one might make about its counter-proposal and Convention Plus, it is clear that it has not been a passive agent or tool of the UK or of the partner countries (Denmark and the Netherlands) that backed the UK's proposals. This augurs well, though, only if UNHCR can maintain this influence and avoid being used as a tool of containment as it has been in the past.

\section{Conclusion}

The relationship between the UK proposals and UNHCR's Convention Plus is a complex one, both conceptually and politically. In both cases, the substance of the proposals has been clouded by obfuscation and poor public relations. However, by the end of 2003, the abandonment of the UK's proposal for transit processing centres on the EU borders means that the debate centres upon the future prospects for regional protection areas. In particular, the UK and UNHCR appear to be moving towards a resettlement policy based on "protected entry procedures." Although the rhetorical emphasis of UNHCR has been mainly on protection and that of the UK mainly on containment and processing, they have reached sufficient consensus to initiate a pilot project for refugees from Liberia.

Two major concerns stem from the direction of the debate: firstly, what impact it will have on spontaneous-arrival asylum, which remains an important channel for many people fleeing human rights abuses; secondly, whether it will be a reversion to the containment strategies of the 1990s, when UNHCR became a tool for its main donor states' policies of exclusion. A tentative identification of the motives underlying the proposals made by both the UK Government and UNHCR provides a starting point for understanding possible methods of contestation that may contribute to avoiding these risks.

The UK's proposals stem, not merely from an identification of asylum seekers with economic cost, but from the nexus of social and political costs associated with their physical presence and the diminishing availability of space in which they can be accommodated in a way that is politically sustainable. Since the massive increase in South-North asylum movement, the UK Government has been trying to shift the burden of asylum domestically in the way that it has seen to be the least electorally damaging (or most electorally enhancing). However, the successive failures of both dispersal and of rural reception centres and the emerging media-state securitization of the post-9/11 spontaneous-asylum "threat" have all removed the "space" available for asylum, leaving extraterritorial burden shifting as amongst the only politically "feasible" strategies. As Robin- son points out, however, this is not an inevitable representation; it emerges from an elite media-political nexus that encourage this particular definition of the "problem." As he suggests, this can most appropriately be contested by reconceptualizing the "problem," re-legitimating asylum seekers, changing the tone of national debate, managing the media, and changing public perception through, for example, education and community involvement. ${ }^{108}$

UNHCR, meanwhile, has been faced with the uneasy balancing act of recognizing these state interests and working within their parameters, on the one hand, and challenging them on the other. The debate over extraterritorial protection is unlikely to be the last time it is faced with the need to make strategic decisions over whether its mandate is best met through innovation, adaptation and compromise, or advocacy of elements of the status quo. Although the details of its consultations with the UK have not been made public, it has successfully managed to shift much of the debate from processing and containment to protection. Whether this is rhetorical or substantive, only time will tell. However, the willingness of the UK to couch all its proposals in relation to the Convention and to negotiate with UNHCR imply that UNHCR continues to maintain its legitimacy and constructive influence on the policy of individual states.

\section{Notes}

1. The word "new" is in inverted commas because, despite the claims that these approaches are "new," extraterritorial initiatives draw on a legacy of precedents, notably Australia's "Pacific Solution" and the U.S.'s use of its naval base on Guantanamo Bay to process Haitian asylum seekers in the case of "transit processing centres," and so-called "safe havens," "humanitarian corridors," "protected entry procedures," and in-country protection in the case of "regional processing zones." Gregor Noll, "Visions of the Exceptional: Legal and Theoretical Issues Raised by Transit Processing Centres and Protection Zones" (working paper, June 2003), <http://www. jur.lu.se/forsake/Noll.nsf $>$ (accessed August 12003 ).

2. Ibid.

3. Lubbers Proposes 'Convention Plus' (Ukraine's UN Office, September 13, 2002), <http://www.un.kiev.ua/en/pressroom/ pressreleases/35/> (accessed May 31, 2003).

4. International Service for Human Rights, monitoring notes for the $53^{\text {rd }}$ Session of ExCom.

5. Agenda for Protection, <http://www.unhcr.ch> (accessed December 5, 2003).

6. "Special Report on Asylum," The Economist, March 15, 2003, $35-38$.

7. New International Approaches to Asylum Processing and Protection, March 2003, <http://www.homeoffice.gov> (accessed May 31, 2003).

8. Amnesty International, Observations to UNHCR's Consultations on Convention Plus, March 7, 2003; Kris Janowski, 
"UNHCR Asylum Policy: Setting the Record Straight," June 2003, <http://www.unhcr.org.uk/press/press_releases2003/ pr2oJun03.htm (accessed August 1, 2003).

9. The word "protection" is used rather than "processing" since regional protection areas, for example, need not imply the processing of asylum claims.

10. Although Christmas Island and the Cocos Islands, for example, are technically Australian territory.

11. This has been expressed both in both Amnesty International's papers, such as Unlawful and Unworkable: Amnesty International's Views on Proposals for Extra-Territorial Processing of Asylum Claims, <http://web.amnesty.org/library/index/ engior610042003>, and in statements such as those of Eve Lester, Refuge Coordinator of A.I.'s International Secretariat at, for example, Sub-Committee F (Social Affairs, Education and Home Affairs) of the House of Lords Select Committee on the European Union, which conducted an inquiry into the proposals for new approaches to the asylum process.; see $<$ http://www.parliament.the-stationery-office.co.uk/pa/ld/l duncorr.htm > (accessed December 10, 2003).

12. Amnesty International, Unlawful and Unworkable, 7.

13. Secure Borders, Safe Haven: Integration with Diversity in Modern Britain (White Paper, February 2002), 13.

14. The leaked letter from Tony Blair to European Council President Costas Simitis revealed that the other EU heads of state were involved in discussion of the proposals, March 10, 2003, $<\mathrm{http}: / /$ www.asylumrights.net/> (accessed August 1, 2003).

15. "Europe's Asylum Policy Shameful, Says UN," Guardian, June 20, 2003, 4, <http://www.guardian.co.uk $>$.

16. For the theoretical background on this debate see "European Burden-Sharing and Forced Migration,"special issue, Journal of Refugee Studies 16, no. 3 (2003).

17. New International Approaches, 5.

18. See, for example, Refugee Council, Unsafe Havens, Unworkable Solutions, May 2003, <http://www.refugeecouncil. org.uk/downloads/policy_briefings/uns afehav_lv_may03. pdf $>$.

19. Statement to Sub-Committee F (Social Affairs, Education and Home Affairs) of the House of Lords Select Committee on the European Union, October 29, 2003.

20. Ruud Lubbers, "Put an End to Their Wandering," Guardian, June 20, 2003, 22.

21. New International Approaches, 6.

22. Statement to Sub-Committee F (Social Affairs, Education and Home Affairs) of the House of Lords Select Committee on the European Union, October 22, 2003.

23. Secure Borders, Safe Haven, 48.

24. Ibid.

25. Ibid., 53.

26. UNHCR's Agenda for Protection is the outcome of its so-called Global Consultations; it is divided into six goals. Goal 3 is "Sharing Burdens and Responsibilities More Equitably and Building Capacities to Receive and Protect Refugees."

27. Agenda for Protection, Overview, 13.

28. New International Approaches, 2.
29. Ruud Lubbers, "Put an End to Their Wandering," 22.

30. Agenda for Protection, 56.

31. Janowski.

32. Groupe d'Information et de Soutien des Immigrés (GISTI) state that "instauration de 'zones de protection régionale'... L’idée est de les [des refugiés] empêcher de poursuivre leur route jusqu'à l'intérieur de l'Union, en leur assurant une 'sécurité' sur place. L'histoire, avec Srebrenica par exemple, nous a appris ce qu'il en était parfois de ces garanties internationales de protection." Comment l'Europe Se Sanctuarise en Créant des Camps Hors de ses Frontières, June 4, 2003, <http:// www.gisti.org/doc/actions/2003/asile/danger.html $>$.

33. Lisa Schuster, The Use and Abuse of Political Asylum in Britain and Germany (London: Frank Cass, 2003), 277.

34. Erika Feller, Director of International Protection, UNHCR, addressing the House of Lords Select Committee on EU Affairs Sub-Committee F, October 22, 2003.

35. Gregor Noll, Jessica Fagerlund, and Fabrice Liebaut, Study on the Feasibility of Processing Asylum Claims outside the EU against the Background of the Common European Asylum System and the Goal of a Common Asylum Procedure, European Commission 2002, 3, <http://europa.eu.int/comm/justice_ home/doc_centre/asylum/common/asylum_study_dchr_20 02_en.pdf $>$.

36. Ibid., 24-30.

37. Alan Travis, "Blunkett Announces First UN Refugees," Guardian, October 3, 2003, <http://www.guardian.co.uk>.

38. Iain Walsh, Deputy Director of the Immigration and Nationality Directorate of the Home Office, addressing the House of Lords Select Committee on EU Affairs Sub-Committee F, October 29, 2003.

39. Sarah Stephens, "Fewer Refugees to Be Allowed to Stay," Green Left Weekly, May 15, 2003, <http://www.greenleft.org.au>.

40. Astri Suhrke, "Burden-Sharing during Refugee Emergencies: The Logic of Collective versus National Action," Journal of Refugee Studies 11, no. 4 (December 1998): 396-415.

41. Jutta Weldes, Constructing National Interests: The United States and the Cuban Missile Crisis (Minneapolis: Minnesota, 1999).

42. Keith Krause and Michael Williams, eds., Critical Security Studies: Concepts and Cases (London: UCL, 1997); Ken Booth, "Security and Emancipation," Review of International Studies 17 (1991): 313-26; Bill McSweeney, Security, Identity and Interests: A Sociology of International Relations (Cambridge: Cambridge University Press, 1999).

43. For example, Amnesty International, Refugee Council, ILPA, and GISTI have all produced reports examining the impact in terms of human rights, as has Noll's Visions of the Exceptional, in particular.

44. The House of Lords Select Committee on EU Affairs SubCommittee F, November 12, 2003.

45. See, for example, Scott Burchill, Richard Devetak, Andrew Linklater, Matthew Paterson, Christian Reus-Smit, and Jacqui True, eds., Theories of International Relations (Basingstoke: Palgrave, 2001). 
46. International relations theory is polarized around a so-called "inter-paradigm debate" between so-called "positivists" and "post-positivists." This dichotomy is particularly apparent in, for example, Steve Smith, Ken Booth, and Marysia Zalewski, eds., International Theory: Positivism and Beyond (Cambridge: Cambridge University Press, 2000). In reality, nearly all IR scholars use both empirical evidence and interpretivist methodology to varying degrees. Where they differ tends to be in the objects of analysis they privilege and the assumptions they make.

47. Niklaus Steiner, "Arguing about Asylum: The Complexity of Refugee Debates in Europe," New Issues In Refugee Research, Working Paper No. 48 (Geneva: UNHCR, 2001); Gil Loescher, The UNHCR and World Politics: A Perilous Path (Oxford: Oxford University Press, 2001), 4.

48. Andrew Shacknove, "American Duties to Refugees: Their Scope and Limits," in Open Borders? Closed Societies? ed. Mark Gibney (New York: Greenwood Press, 1988).

49. Gil Loescher, "Introduction: Refugee Issues in International Relations," in Refugees and International Relations, ed. Gil Loescher and Laila Monahan, (Oxford: Clarendon, 1990), 11-17; Gil Loescher, Refugee Movements and International Security, Adelphi Papers 268 (London: Brassey, 1992); Gil Loescher, Beyond Charity (Oxford: Oxford University Press, 1993), 18-23.

50. Loescher, The UNHCR and World Politics, 13.

51. Steiner, 16.

52. Ibid., 8 .

53. Eiko Thielemann, "Between Interests and Norms: BurdenSharing in the European Union," Journal of Refugee Studies 16, no. 3 (2003): 253-73.

54. Alexander Betts, "Public Goods Theory and the Provision of Refugee Protection: The Role of the Joint-Product Model in Burden-Sharing Theory," Journal of Refugee Studies 16, no. 3 (2003): 274-96.

55. Christina Boswell, "Explaining European Public Policy Responses to Asylum and Migration" (paper presented at the UNHCR-WIDER Conference on Poverty, International Migration and Asylum, Helsinki, 27-28 September 2002).

56. Don Flynn, "Tough as Old Boots": Asylum, Immigration and the Paradox of New Labour Policy (London: JCWI, 2003), $<$ http://www.jcwi.org.uk> (accessed December 10, 2003).

57. This was the opinion expressed by Richard Williams of the Refugee Council at the Immigration Rights Project discussion forum where Don Flynn's paper was discussed, December 4, 2003.

58. Schuster, 175.

59. Alexander Betts, "The Political Economy of Extra-Territorial Processing: Separating 'Purchaser' from 'Provider' in Asylum Policy,” New Issues in Refugee Research, Working Paper No. 91 (Geneva: UNHCR, 2003).

60. Noll, Visions of the Exceptional, 20-22.

61. "Asylum Cost under Fire," BBC, April 11, 2000, http://www. bbc.co.uk; "Asylum Error to Cost UK Millions," Guardian, October 2, 2003, <http://politics.guardian.co.uk>; "Letwin:
Asylum Cuts Will Fund Policing," Guardian, October 7, 2003, $<$ http://politics.guardian.co.uk>; "Asylum Seeker Dispersal 'A Waste of Money,'” Guardian, July 30. 2003, <http://www. guardian.co.uk>; "Asylum Cost Hits Eurotunnel," Telegraph, January 23, 2002, <http://www.telegraph.co.uk>.

62. The House of Lords Select Committee on EU Affairs SubCommittee F, October 29, 2003.

63. Oxfam, "Budgeting for Overseas Processing", <http://www. caa.org.au/campaigns/refugees/still_drifting/budgeting. html> (accessed August 1, 2003).

64. Megan Saunders, "Costs Soar for Island Detainees," The Australian, April 16, 2002, <http://www.labor4refugees.org/>.

65. Refugee Council, Unsafe Havens, Unworkable Solutions, 8.

66. IPLA, IPLA's Submission to the House of Lords Select Committee on the European Union on New Approaches to Asylum Processing, <http://www.ilpa.org.uk/NewApproachestotheAsylumProcess.html $>$ (accessed December 10, 2003).

67. Noll, Fagerlund, and Liebaut, 3.

68. This is acknowledged by the Home Office in Secure Borders, Safe Haven, 65; see also Gregor Noll, "Rejected Asylum Seekers: The Problem of Return," New Issues in Refugee Research, Working Paper No. 5 (Geneva: UNHCR, 1999).

69. Vaughan Robinson, "Defining the Problem" and "'Dispersal Policies in the UK," in Spreading the 'Burden'? A Review of Policies To Disperse Asylum Seekers and Refugees, ed. Vaughan Robinson, Roger Andersson, and Sako Musterd (Bristol: Policy Press, 2003), chapters 2 and 5, 3-24 and 103-47.

70. Schuster, 167.

71. Robinson, 103-47.

72. Christina Boswell, "Burden-Sharing in the European Union: Lessons from the German and UK Experience," Journal of Refugee Studies 16, no. 3 (2003): 316-35.

73. Ibid., 324.

74. Alice Bloch, The Migration and Settlement of Refugees in Britain (London: Palgrave, 2002), 54.

75. Asylum Statistics United Kingdom 2001, <http://www.homeoffice.gov.uk/rds/pdfs2/hosb902.pdf>, 42-44; "BNP Take Tally to 18 Councillors," Guardian, September 5, 2003, $<$ http://www.guardian.co.uk $>$.

76. This is one of the main slogans on the BNP Web site, <http:// www.bnp.org $>$ (accessed August 1, 2003).

77. Robinson, 167-71.

78. <Http://www.bag2002.co.uk> (accessed August 1, 2003).

79. "Fear of the Unknown Cranked up by Tabloids," Guardian, February 6, 2003, <http://www.guardian.co.uk>.

80. "Increase in Asylum Seekers 'Threatens Unrest," Guardian, May 8, 2003, <http://www.guardian.co.uk>.

81. "Halving of Asylum Claims in Sight," Guardian, August 28, 2003, <http://www.guardian.co.uk>.

82. "The Numbers Game," Guardian, August 29, 2003, <http:// www.guardian.co.uk $>$.

83. "Blair Targets Huge Asylum Cuts," Guardian, August 2, 2003, $<$ http:// www.guardian.co.uk $>$.

84. Schuster, 175.

85. David Blunkett, Foreword, Secure Borders, Safe Haven. 
86. Ibid., 13.

87. New International Approaches, 1.

88. "Blunkett Announces First UN Refugees," Guardian, October 3, 2003, <http://www.guardian.co.uk>.

89. Claudia Tazreiter, "Asylum-Seekers as Pariahs in the Australian State: Security against the Few," Discussion Paper No. 2003/19, UN-WIDER, February 2003, <http://www.wider. unu.edu>.

90. Andrew Green, Daily Mail, March 1, 2003, <http://www.migrationwatch.co.uk/p_DailyMail_1Mar.asp $>$.

91. Susan Bisset and Chris Hastings, "Taliban Who Fought British Troops Is Granted Asylum Here,” January 1, 2003, $<\mathrm{http}: / /$ www.telegrapgh.co.uk $>$.

92. Steiner, 5-6.

93. Boswell, Explaining European Public Policy Responses, 4-5.

94. See, for example, Alexander Aleinikoff and Vincent Chetail, eds., Migration and International Legal Norms (Hague: Asser, 2003); Gregor Noll, Negotiating Asylum (Hague: Nijhoff, 2000) for a discussion on the role of norms in asylum policy.

95. Loescher, The UNHCR and World Politics, 12-14.

96. B.S. Chimni, "The Geopolitics of Refugee Studies: A View from the South," Journal of Refugee Studies 11, no. 4 (1998): 365-68.

97. Mikhael Barutciski, "The Reinforcement of Non-Admission Policies and the Subversion of UNHCR," International Journal of Refugee Law 8, no. 1 (1996): 49-110.

98. Cecile Dubernet, The International Containment of Displaced Persons (Aldershot: Ashgate, 2001).

99. Betts, "Public Goods Theory and the Provision of Refugee Protection," 290-91.

100. Loescher, The UNHCR and World Politics, 4-8.

101. Lubbers, "Put an End to Their Wandering".

102. Agenda for Protection, 58.

103. The House of Lords Select Committee on EU Affairs SubCommittee F, November 12, 2003.

104. Amnesty International, Unlawful and Unworkable, 10-13.

105. Ibid., 8.

106. Lubbers, Agenda for Protection, Foreword, 6.

107. The House of Lords Select Committee on EU Affairs SubCommittee F, October 22, 2003.

108. Robinson, 171.
Alexander Betts, B.A. (hons), M.Sc., is a graduate student at St. Antony's College, Oxford University. He has previously published on the international relations of forced migration in the Journal of Refugee Studies and UNHCR's Working Paper Series, New Issues In Refugee Research. He has worked with asylum seekers in the Netherlands and the UK and as an intern for the International Service for Human Rights in Geneva. 